\title{
Role of Bioinoculants for Improving Growth and Yield of Okra (Abelmoshuses culentum)
}

\author{
Munazza Rafique*, Aneela Riaz, Ashfaq Anjum, M. Amjad Qureshi, Fakhar Mujeeb
}

Soil Bacteriology Section, Ayub Agricultural Research Institute, Faisalabad, Pakistan

\begin{abstract}
Copyright $\subseteq 2018$ by authors, all rights reserved. Authors agree that this article remains permanently open access under
\end{abstract} the terms of the Creative Commons Attribution License 4.0 International License

\begin{abstract}
Elevated use of agrochemicals has been the backbone of sustainable crop production. However, the environmental hazards, soaring cost and stagnant production are the foremost issues affiliated with them. Exploitation of stumpy cost and environment friendly plant growth promoting rhizobacteria (PGPR) has certain encouraging results regarding sustainability in agricultural production. A glass house study was conducted at Soil Bacteriology Section, Ayub Agricultural Research Institute, Faisalabad to check the efficacy of different PGPR for growth and yield of okra (Abelmoshuses culentum). Treatments were control, Azotobacter sp inoculation, Azospirillum sp inoculation, Bacillus sp inoculation, Pseudomonas sp inoculation and Rhizobium sp inoculation. Results revealed that there was significant effect of all inoculants on growth and yield of okra crop. An increase of $23.5 \%$ and $21.0 \%$ in green pod yield was recorded with Pseudomonas sp and Bacillus sp, respectively. Positive consequence was observed in all other parameters where Pseudomonas inoculation was applied as compared to no inoculation. This study suggests that PGPR may be a dynamic biofertilizer to boost the yield of okra and other agricultural crops.
\end{abstract}

Keywords Bioinoculants, Growth, Okra, PGPR, Yield

\section{Introduction}

Influential role of soil beneficial microorganism is not only restricted to plant growth but also have a key function in sustainable agriculture development and environmental protection. Plant growth promoting rhizobacteria (PGPR) that resides in the rhizosphere of plants, increase growth by direct and indirect mechanisms like nitrogen fixation, solubilization of nutrients ( $\mathrm{P}, \mathrm{K}, \mathrm{Zn}$ etc.) and siderophore production etc. Bhattacharya and Jha.,[29]. Alternatively PGPR supplement the role of chemical fertilizers, pesticides and other inputs. Plant and rhizobial interaction may be positive, negative or neutral Whipps., [19]. Organic substances i.e. biofertilizer restrain the innumerous microbes that increases the root growth as applied to the seed or directly on soil in the vicinity of plants. Azotobacter, Azospirillum, Bradyrhizobium, Mesorhizobium, and Bacillus are considered as the efficient PGPR strains for their aptitude to execute as biofertilizer by Vessey., [39]. These bacteria build colonies in rhizosphere to form relationship on the external surface or even intercellular spaces of roots McCully., [26]. Plant growth regulators like IAA, gibberellic acid, and cytokinins produced by PGPR amend the root structure; therefore prop up plant development Kloepper et al., [20]. In literature, various PGPR, free-living rhizobacteria and symbiotic species are reported to excrete auxin and gibberellic acid in the rhizosphere playing proficient role in improving the surface area of root Han et al., [18]. Although nitrogen and phosphorus are fundamental nutrients but $\mathrm{P}$ is more frequently required for the smooth completion of plant's life cycle. Nevertheless, a small amount of $\mathrm{P}$ is available to plants in spite of huge pools of total soil P. This sparse availability of $\mathrm{P}$ is due to insoluble forms of soil $\mathrm{P}$ while plants can absorb it only in the form of monobasic $\left(\mathrm{HPO}_{4}\right)$ and dibasic $\left(\mathrm{H}_{2} \mathrm{PO}_{4}\right)$ ions. Different phosphate solubilizing microorganisms (PSMs) are reported, which transform the insoluble form of $\mathrm{P}$ to soluble form by the releasing organic acids and producing proton through acidification Richardson et al.,[6] which help exchange and chelation process Hameeda et al., [7]. For P solubilization, different saprophytic bacteria and fungi also share chelation-mediated mechanisms Whitelaw., [25]. Similarly, plant root exudates and organic compounds may also modify the P concentration in soil solution Hinsinger., [28]. Nitrogen is the liveliest nutrient for plants but due to rainfall, land mineral and leaching losses it has become a restrictive factor in the agricultural production. However, instead of chemical fertilizers, use of various plant growth promoting, symbiotic and non-symbiotic nitrogen fixing bacteria in soil, may improve crop yield Vessey., [39]. In legumes, symbiotic $\mathrm{N}_{2}$ fixation with inoculation of effective PGPR is well known. Rhizobium is the major symbiotic $\mathrm{N}_{2}$ fixer, while non-symbiotic $\mathrm{N}$ - fixation is 
regulated by free-living microbes like diazotrophs Bashan and de-Bashan., [40]. Numerous researchers have studied plant growth improvement with the combined inoculation of symbiotic and non-symbiotic microorganisms. A number of PGPR are already well-recognized for the emergence of seed, enhanced plant growth, improved crop production and development of agriculture Minorsky.,[30]. Inoculation of PGPR improves different agronomic properties of plants like total biomass, chlorophyll contents and leaf area Baset Mia et al.,[24]. The significant focus of PGPR use in agriculture has been the rising demand of food and improving environment quality Dobbelaere et al., [35]. These PGPR are effectively being used in raising all agricultural crops, fruits and vegetables. Okra (Abelmoschus esculentus L.) is a popular and wholesome vegetable grown worldwide due to its taste and nutritious qualities. Its green and tender fruits are cooked as vegetable and are used in a variety of food delicacies. It is rich in vitamins, macronutrients and other minerals etc. The present study was meant to assess the response of different plant growth promoting microbes on growth and yield of okra.

\section{Materials and Methods}

\section{Isolation of Bacteria:}

Dilution plate technique was used for isolation of Azotobacter, Bacillus, Pseudomonas and Azospirillum. Bacillus was isolated by subjecting rhizospheric soil suspension to heat shock at $80^{\circ} \mathrm{C}$ in an oven for 30 minutes by Claus., [11] and specific medium was got inoculated after cooling that soil suspension Nautiyal., [34]. These Inoculated streaked petri plates with the specific medium were incubated at $28 \pm 2{ }^{\circ} \mathrm{C}$ for one week. Growth was picked and sub cultured to get a pure culture on selective medium. For the isolation of Rhizobium $s p$. roots were washed gently with tap water to remove soil. The nodules were detached from roots and consigned in Petri-plates. For sterilization, the nodules were dipped into $95 \%$ ethanol followed by $0.2 \% \mathrm{HgCl}_{2}$ solution for 3-5 minutes and 5-6 washings with sterilized water were also given Russell et al., [8]. Then the nodules were crushed with the help of sterilized glass rod in the presence of few drops of water to obtain suspension. The suspension material was streaked on yeast extract mannitol agar medium (YMA) with the help of inoculating needle Vincent., [27].To obtain pure culture, prolific single colonies were selected and re-streaked on fresh prepared plates. Stored the purified rhizobial cultures at $5 \pm 1{ }^{\circ} \mathrm{C}$ on slants and preserved for further experimentation following preliminary screening, standard methods [Gram $(+)$, Catalase $(+)$, starch hydrolysis (-) and citrate utilization $(+)]$ as outlined in Bergey's Manual of Systematic Bacteriology Krieg and Holt., [33].

\section{Determination of Auxin Production}

Auxin production of Rhizobium, Bacillus, Pseudomonas, Azotobacter and Azospirillum was determined colorimetrically in terms of IAA equivalents. The isolates were cultured on their respective broth media for 72 hours. After centrifugation, $3 \mathrm{ml}$ of supernatants were mixed with $2 \mathrm{ml}$ Salkowski's reagent $\left(2 \mathrm{ml}\right.$ of $0.5 \mathrm{M} \mathrm{FeCl}_{3}+98 \mathrm{ml}$ of $35 \% \mathrm{HClO}_{4}$ ), incubated the mixture at room temperature for $30 \mathrm{~min}$ for color development and absorbance was measured at $535 \mathrm{~nm}$ using spectrophotometer. Auxin concentration produced by bacterial isolates was determined with the help of standard curve Sarwar et al., [23]. For the study the isolates with highest auxin biosynthesis were selected.

\section{Phosphate Solubilization of Isolates}

The solubilization capacity of Pseudomonas Ps1, Ps2, Ps3, Ps4, Ps5 and Bacillus isolates Bs1, Bs2, Bs3, Bs4, Bs5, were checked on Pikovskaya's medium containing $\left(\mathrm{g} \mathrm{L}^{-1}\right)$ : glucose 10, $\mathrm{Ca}_{3}\left(\mathrm{PO}_{4}\right)_{2}$ 5.0, $\left(\mathrm{NH}_{4}\right)_{2} \mathrm{SO}_{4} \quad 0.5, \mathrm{NaCl} 0.2$, $\mathrm{MgSO}_{4} \cdot 7 \mathrm{H}_{2} \mathrm{O} 0.1, \mathrm{KCl} 0.2$, yeast extract $0.5, \mathrm{MnSO}_{4} \cdot \mathrm{H}_{2} \mathrm{O}$ 0.002 , and $\mathrm{FeSO}_{4} \cdot 7 \mathrm{H}_{2} \mathrm{O} 0.002$ and agar 17 while the $\mathrm{pH}$ was adjusted to 7 before autoclaving Pikovskaya., [17]. These isolates were capable to solubilize insoluble phosphates in the Pikovskaya's medium by halo zone formation. The growth and solubilization diameter were determined after incubation at $28 \pm 2^{\circ} \mathrm{C}$ for seven days. On the basis of diameter of clearing halo zones, solubilization efficiency, SE, Gaur., [5], Nguyen et al., [9] was calculated by the formula;

\section{$\mathrm{SE}=$ solubilization diameter $\times 100 /$ Growth diameter}

\section{Bacterial Inoculum Preparation}

Inocula of Bacillus, Pseudomonas, Azotobacter and Azospirillum were prepared in their selective media while Rhizobium culture was prepared in yeast extract mannitol (YEM) medium Nautiyal., [34]. All the media were inoculated in $500 \mathrm{ml}$ conical flasks containing $250 \mathrm{ml}$ medium and incubated at $28+2^{\circ} \mathrm{C}$ and shaked at $100 \mathrm{rpm}$ for three days.

\section{Seed Bacterization}

Peat as carrier was sterilized at $121^{\circ} \mathrm{C}$ and $15 \mathrm{psi}$ pressure for one hour then inoculated with broth culture. Peat-based inoculum was incubated at $28 \pm 2^{\circ} \mathrm{C}$ by adding $10 \%$ sugar solution to raise the microbial population. For inoculation, the desired suspension of inoculum $\left(10^{7}-\right.$ $10^{8} \mathrm{CFUml}^{-1} ; 250 \mathrm{mlkg}^{-1}$ peat) was mixed with sterilized peat and incubated for $24 \mathrm{~h}$ at $28 \pm 2^{\circ} \mathrm{C}$ before use for seed coating (seed to peat ratio 1.25:1 w/w). Okra seed dressing was prepared with the inoculated peat, mixed with $10 \%$ sterilized sugar (sucrose) solution, in a 10:1 ratio. In the case of un-inoculated, control, seeds were coated with the sterilized peat treated with sterilized broth and $10 \%$ sterilized sugar solution. 


\section{Glass House Study}

A pot experiment was conducted at Soil Bacteriology Section, Ayub Agricultural Research Institute, Faisalabad, Pakistan, to check the effectiveness of different plant growth promoting rhizobacteria on the plant growth and yield of okra. Thoroughly mixed air dried soil passed through 2-mm sieve and tested for various physicochemical characteristics. i.e. Medium textured soil with $\mathrm{pH} 7.8$, EC $1.9 \mathrm{~d} \mathrm{Sm}^{-1}, \mathrm{~N} 0.030 \%$ and available $\mathrm{P} 9.8$ $\mathrm{mg} \mathrm{kg}^{-1}$. Surface sterilization of okra seeds were carried out by using $3 \%$ solution of sodium hypo chloride for $2 \mathrm{~min}$, followed by 2-3 washings (one minute duration) with sterile distilled water. No microbial growth was observed against nutrient agar plates while checking the effectiveness of surface sterilization of seeds. Four seeds pot $^{-1}$ were sown in a pot containing $16 \mathrm{~kg}$ of soil. After germination two plants were maintained in each pot. Pots of every treatment with three repeats were placed in the glass house by using a completely randomized design (CRD). Recommended dose of $\mathrm{N}, \mathrm{P}$, and $\mathrm{K}$ fertilizers $\left(100-70-50 \mathrm{~kg} \mathrm{ha}^{-1}\right)$ was used to all pots and the same amount of water was applied to the pots whenever they required.

\section{Bioinoculant Treatments}

Following treatments were used: 1) Un inoculated, 2) Azotobacter sp, 3) Azospirillum sp, 4) Bacillus sp, 5) Pseudomonas sp, 6) Rhizobium sp. Inoculum treated slurry was used for coating of seed. Slurry with sterilized LB broth was used for control treatment.

\section{Plant Growth Parameters}

Data regarding growth and yield parameters of okra was recorded before and after harvesting.

\section{Agronomic Parameters}

Plant height, internodal distance and root length were recorded using measuring tape. Number of leaves plant ${ }^{-1}$ and Number of pods plant ${ }^{-1}$ were counted at reproductive growth stage. Green pod yield plant ${ }^{-1}$, root, shoot fresh and dry weight were recorded after harvesting of okra. The soil from each pot was washed away to collect root samples. Both shoot and root samples were thoroughly washed with distilled water and then blotted dry with tissue papers before sun drying. Sun dried plants were placed in an oven at $72^{\circ} \mathrm{C}$ for $72 \mathrm{~h}$ until constant weight was achieved.

\section{Screening of Isolates}

In laboratory study, all the isolates were screened on the basis of auxin (expressed as IAA equivalents, P-solubilization efficiency and some biochemical tests. Isolates Ps9 and Bs2 showed highest biosynthesis potential and phosphate solubilization were selected for experimentation. Efficient strains were mentioned in table 3.

\section{Soil and Plant Analysis}

Pre and post soil analysis were carried for determination of $\mathrm{N}$ and $\mathrm{P}$. Fruit $\mathrm{N}$ and $\mathrm{P}$ concentration was determined after crop harvest.

\section{Statistical Analysis}

To analyzed data software Statistix 8.1 (Analytical Software, USA) was used. Least significant difference test Steel et al., [12] was used to compare means of treatments.

\section{Results}

Response of bioinoculants on okra growth and yield is shown in Table 1, and 2. The response of PGPR applications on yield of okra was statistically significant.

\section{Yield Parameters}

Highest green pod yield (26.12 $\left.\mathrm{g} \mathrm{plant}^{-1}\right)$ and number of pods plant ${ }^{-1}(6.75)$ in $\mathrm{T}_{4}$ was produced with Pseudomonas inoculation followed by Bacillus inoculation $(25.66 \mathrm{~g}$ plant $^{-1}$ ) and (6.25) respectively as compared to uninoculated control i.e.21.14 $\mathrm{g} \mathrm{plant}^{-1}$, 4.5. Hundred seed weight was higher in case of Azotobacter, Azospirillum and Rhizobium inoculation as compared to control but maximum $(6.5 \mathrm{~g})$ weight was achieved in case of Bacillus sp application.

\section{Agronomic Parameters}

Effects of different bacterial culture on root length, root fresh and dry biomass, are presented in table 2 . Significant increase in the root length, root fresh and dry biomass was observed by inoculations of different plant growth promoting bacteria enhanced as compared to non-inoculated plant. Maximum root length, root fresh and dry mass were obtained in Bacillus treatment viz. $46.80 \mathrm{~cm}$, 10.90 and 2.20 g plant $^{-1}$ followed by Pseudomonas seed treatment $\left(46.50 \mathrm{~cm}, 9.10\right.$ and $\left.1.8 \mathrm{~g} \mathrm{plant}^{-1}\right)$. Minimum plant height and shoot fresh and dry mass were obtained without inoculation i.e. $32.25 \mathrm{~cm}, 32.70$ and 6.0 g plant $^{-1}$ while maximum plant height and shoot fresh and dry mass were observed in $\mathrm{T}_{4}\left(45 \mathrm{~cm}, 37.20\right.$ and $9.0 \mathrm{~g} \mathrm{plant}^{-1}$ respectively).

\section{Physiological Parameters}

Maximum number of leaves per plant (10.70) was recorded in $\mathrm{T}_{3}$ as compared to uninoculated i.e. 6.0. Maximum $(3.7 \mathrm{~cm})$ internodal distance was observed where Bacillus sp was applied as compared to other treatments and minimum $(3.08 \mathrm{~cm})$ distance was measured without inoculation.

\section{Chemical Parameters}

Regarding soil analysis, maximum soil $\mathrm{N}(0.040 \%)$ was observed in case of Azotobacter inoculation followed by 
Azospirillum (0.037\%), Pseudomonas (0.038\%), Bacillus $(0.035 \%)$ and Rhizobium (0.036\%) at 100-70-50 kg NPK $\mathrm{ha}^{-1}$. While maximum soil P (12.9 ppm) was observed with Pseudomonas inoculation as compared to control (9.5 ppm) which did not differ significantly from Bacillus inoculation.

Nitrogen \% obtained in okra fruit was 2.46, 2.69, 2.64 and 2.57 where seed were treated with Azospirillum, Bacillus, Pseudomonas, Rhizobium, respectively, as compared to control (2.18\%) however, maximum (3.05\%) $\mathrm{N}$ was observed where Azotobacter was used. Highest $\mathrm{P}$ $(0.49 \mathrm{ppm})$ contents were recorded where Bacillus inoculation was done as compared to control (0.28 ppm).

\section{Discussion}

The results exposed that plant physiology and growth can be enhanced by PGPR inoculation. It was due to higher survival rate, more plant root/shoot weight and yield when compared with non-treated. Increase in plant height with the application of PGPR was also observed by Asghar et al., [16] and Gholami et al., [2]. It is recommended that PGPR applications like Pseudomonas and Bacillus species can revitalize plant growth and boost yield in tomato and pepper Sahin et al., [15], Çakmakci et al., [31], sugar beet by Elkoca et al., [13] and barley Salantur et al., [4]. Eşitken et al., [1] concluded that plant growth can be increased by $\mathrm{N}$-fixing capability of PGPR. These findings were similar to our results where Pseudomonas and Bacillus produced highest green pod yield ( $26.12 \mathrm{~g}, 25.66 \mathrm{~g}$ respectively) than untreated one $(21.14 \mathrm{~g})$. Results of several studies validated that seed inoculation with PGPR have increased the plant growth parameters and several crops yield Gravel et al., [36,37]. In our findings, maximum leaf area and leave numbers were observed following seeds inoculation with Azotobacter sp.
Appliance of bacterial inoculum on rice, wheat and maize like cereal sand sugar beet has reportedly fixed nitrogen, solubilized phosphorus and produced plant growth hormones and ultimately increased yield Salantur et al., [4], Egamberdiyeva et al.,[10]. Similarly, PGPR inoculated okra also showed significant increase in plant root and shoot biomass in comparison to the un-inoculated. Maximum shoot mass $37.2 \mathrm{~g}$ plant $^{-1}$ was obtained in treatment that was inoculated with Pseudomonas with respect to control $\left(32.7 \mathrm{~g}\right.$ plant $\left.^{-1}\right)$. Inoculated maize with PGPR found significant response in plant biomass compared to the control. The maximum increase of $53.72 \%$ and $108.71 \%$ for root and shoot weight, respectively, was obtained in plants inoculated with Pseudomonas fluorescens. Numerous bacterial mechanisms along production of hormones, may have controlled growth of root and development Mantelin and Touraine.,[36]. The highest root fresh weight $21.75 \mathrm{~g}$ was observed where seeds were treated with Bacillus sp when compared with control $(11.54 \mathrm{~g})$.

Plant growth promoting hormones like IAA and GA3, released by Azotobacter and Rhizobium strains, improve the plants growth. Productions of organic acids by $\mathrm{P}$ solubilizing bacteria perk up the $\mathrm{P}$ availability and thus stimulate plant growth Maliha et al., [32].

Seed treatment with PGPR is a well-recognized practice to augment yield and growth of crops. Yildirim et al., [14] also suggested an increase in micro and macro nutrients uptake by broccoli when treated with bacterial inoculum.

This study also endorsed the buoyant effects of PGPR application on the yield and growth of okra pods. Inoculation of okra seeds by Azotobacter, Azospirillum, Bacillus, Pseudomonas and Rhizobium is an effectual approach for sustainable yield of agricultural crops. Hence, the findings of the study recommend that PGPR may be used as biological fertilizer to enhance the yield of okra.

Table 1. Effect of different plant growth promoting bacteria on growth and yield of okra

\begin{tabular}{|c|c|c|c|c|c|}
\hline Treatments & $\begin{array}{l}\text { Plant height } \\
\text { (cm) }\end{array}$ & $\begin{array}{c}\text { No of leaves } \\
\text { plant }^{-1}\end{array}$ & $\begin{array}{c}\text { Internodal } \\
\text { distance }(\mathrm{cm})\end{array}$ & $\begin{array}{l}\text { No of pods } \\
\text { plant }^{-1}\end{array}$ & $\begin{array}{c}\text { Green Pod Yield } \\
\left(\text { gplant }^{-1}\right)\end{array}$ \\
\hline T1:Un-inoculated & $32.25 \mathrm{~d}$ & $6.00 \mathrm{c}$ & $3.08 \mathrm{bc}$ & $4.50 \mathrm{c}$ & $21.14 \mathrm{c}$ \\
\hline T2: Azotobacter & $37.25 \mathrm{bc}$ & $9.00 \mathrm{~b}$ & $3.10 \mathrm{bc}$ & $6.00 \mathrm{ab}$ & $23.16 \mathrm{~b}$ \\
\hline T3:Azospirillum & $35.00 \mathrm{~cd}$ & $10.70 \mathrm{a}$ & $3.20 \mathrm{~b}$ & $6.00 \mathrm{ab}$ & $24.05 b$ \\
\hline T4:Bacillus & $45.00 \mathrm{a}$ & $9.33 \mathrm{ab}$ & $3.70 \mathrm{a}$ & $6.25 \mathrm{ab}$ & $25.66 \mathrm{a}$ \\
\hline T5:Pseudomonas & $40.00 \mathrm{~b}$ & $10.00 \mathrm{ab}$ & $2.93 \mathrm{c}$ & $6.75 \mathrm{a}$ & $26.12 \mathrm{a}$ \\
\hline T6:Rhizobium & $36.00 \mathrm{c}$ & $10.33 \mathrm{ab}$ & $2.48 \mathrm{~d}$ & $5.63 \mathrm{~b}$ & $25.20 \mathrm{a}$ \\
\hline LSD & 3.4928 & 1.6240 & 0.2519 & 1.676 & 2.432 \\
\hline
\end{tabular}

* Values are the mean of three repeats same letters are not statistically different at $\mathrm{P}<0.05$ according to the least significant difference (LSD) test. 
Table 2. Effect of different plant growth promoting bacteria on root parameter and soil analysis after harvesting

\begin{tabular}{cccccc}
\hline Treatments & $\begin{array}{c}\text { Root length } \\
(\mathbf{c m})\end{array}$ & $\begin{array}{c}\text { Root fresh biomass } \\
\left.\text { (gplant }^{-1}\right)\end{array}$ & $\begin{array}{c}\text { Root dry biomass } \\
\left.\text { (g plant }^{-1}\right)\end{array}$ & $\begin{array}{c}\text { At Crop Harvest } \\
\text { N content }\end{array}$ & Available P(ppm) \\
\hline T1:Un-inoculated & $30.80 \mathrm{e}$ & $5.8 \mathrm{~d}$ & $1.2 \mathrm{~d}$ & $0.031 \mathrm{c}$ & $9.5 \mathrm{c}$ \\
T2: Azotobacter & $39.90 \mathrm{~b}$ & $7.3 \mathrm{c}$ & $1.5 \mathrm{c}$ & $0.040 \mathrm{a}$ & $11.0 \mathrm{~d}$ \\
T3:Azospirillum & $35.10 \mathrm{c}$ & $7.2 \mathrm{c}$ & $1.4 \mathrm{c}$ & $0.035 \mathrm{~b}$ & $11.9 \mathrm{~b}$ \\
T4:Bacillus & $46.55 \mathrm{a}$ & $10.9 \mathrm{a}$ & $2.2 \mathrm{a}$ & $0.037 \mathrm{ab}$ & $12.5 \mathrm{a}$ \\
T5:Pseudomonas & $46.80 \mathrm{a}$ & $9.1 \mathrm{~b}$ & $1.8 \mathrm{~b}$ & $0.038 \mathrm{ab}$ & $12.9 \mathrm{a}$ \\
T6:Rhizobium & $32.90 \mathrm{~d}$ & $8.9 \mathrm{~b}$ & $1.8 \mathrm{~b}$ & $0.036 \mathrm{~b}$ & $11.7 \mathrm{~b}$ \\
LSD & 1.115 & 0.884 & 0.169 & 3.533 & 0.4547 \\
\hline
\end{tabular}

* Values are the mean of three repeats same letters are not statistically different at $\mathrm{P}<0.05$ according to the least significant difference (LSD) test.

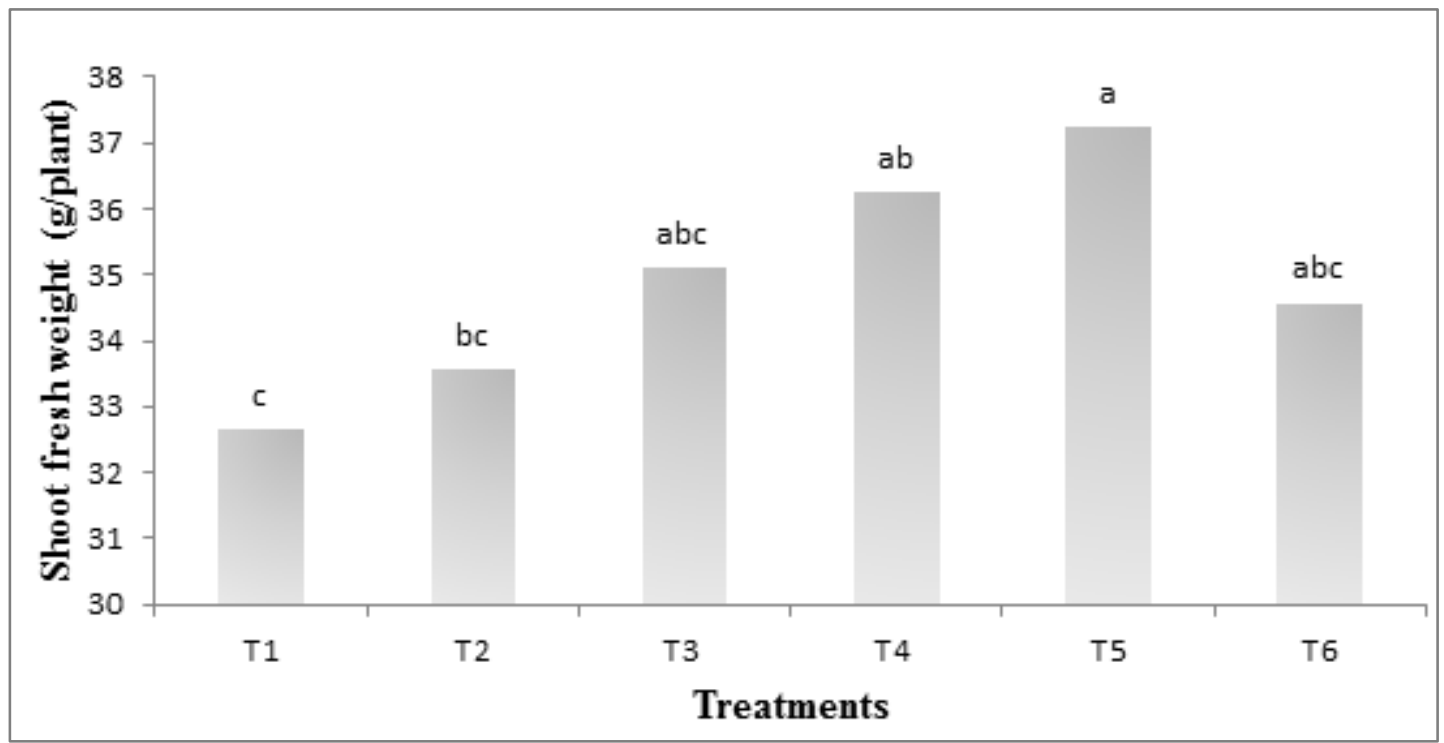

Figure 1. Response of different PGPRs to shoot fresh biomass (g plant $\left.{ }^{-1}\right)$

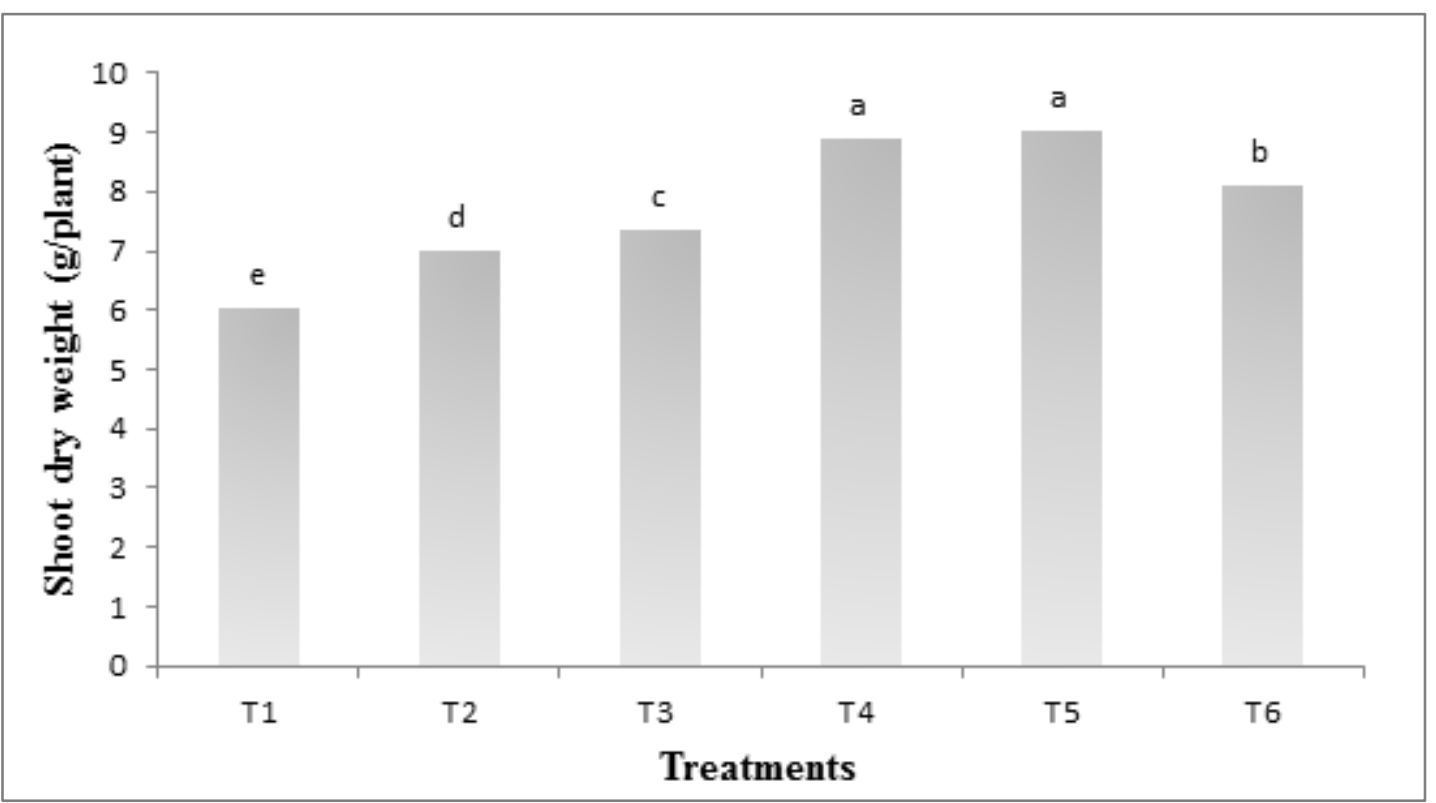

Figure 2. Response of different PGPRs to shoot dry biomass ( $\left.\mathrm{g}_{\text {plant }}{ }^{-1}\right)$ 


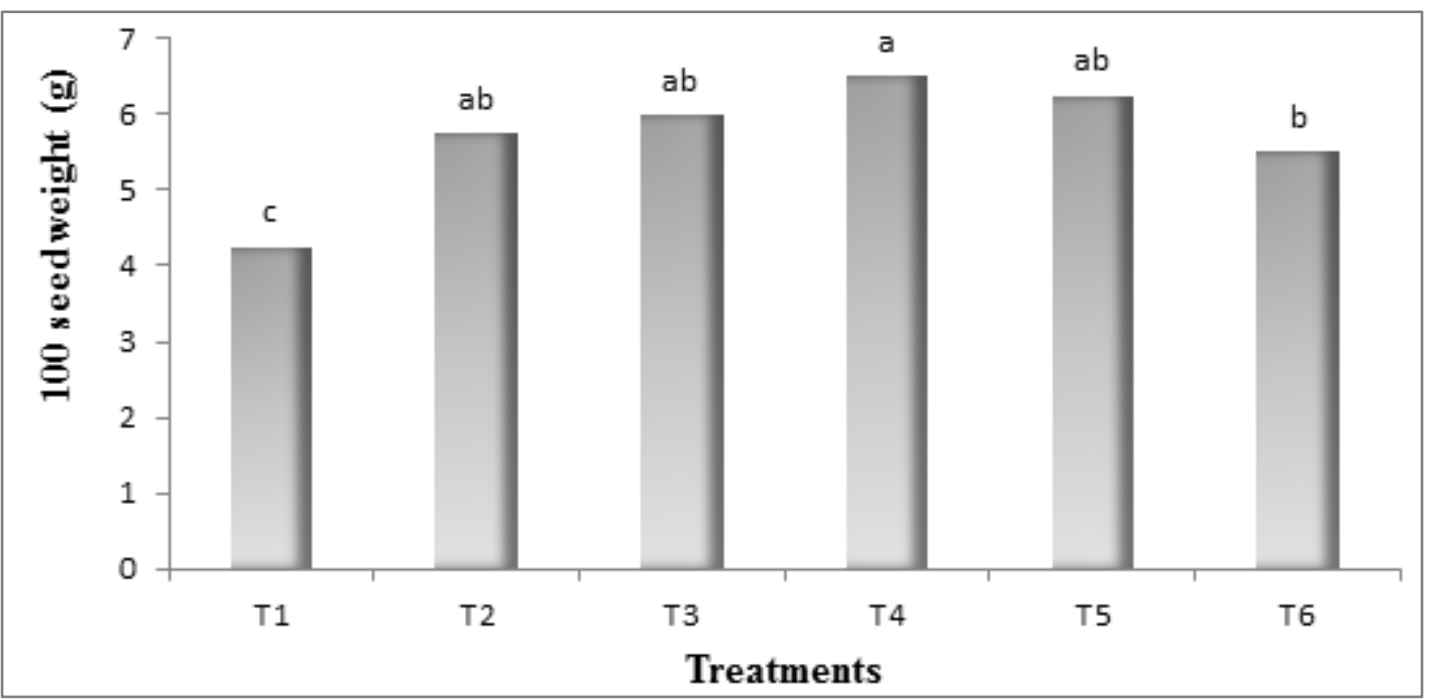

Figure 3. Response of different PGPRs on 100 seed weight (g)

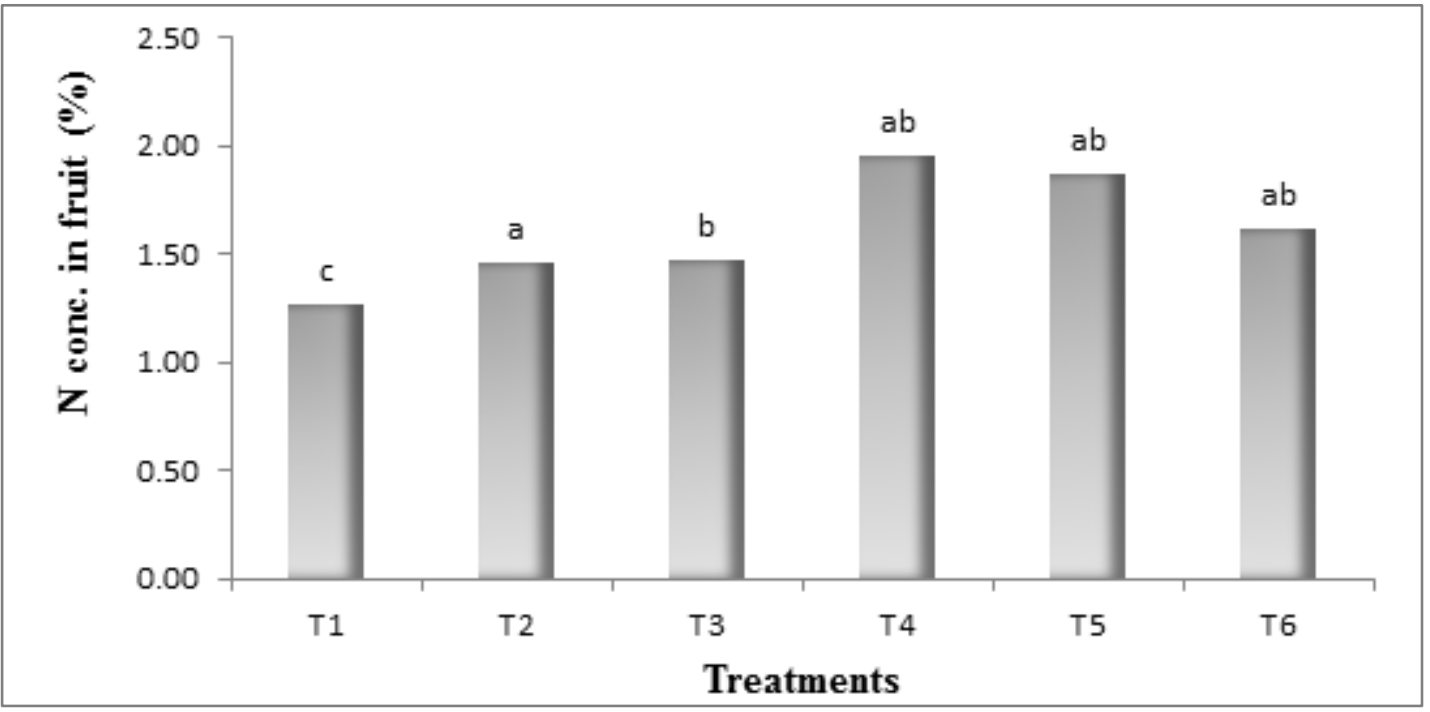

Figure 4. Response of different PGPRs on $\mathrm{N}$ concentration in fruit (\%)

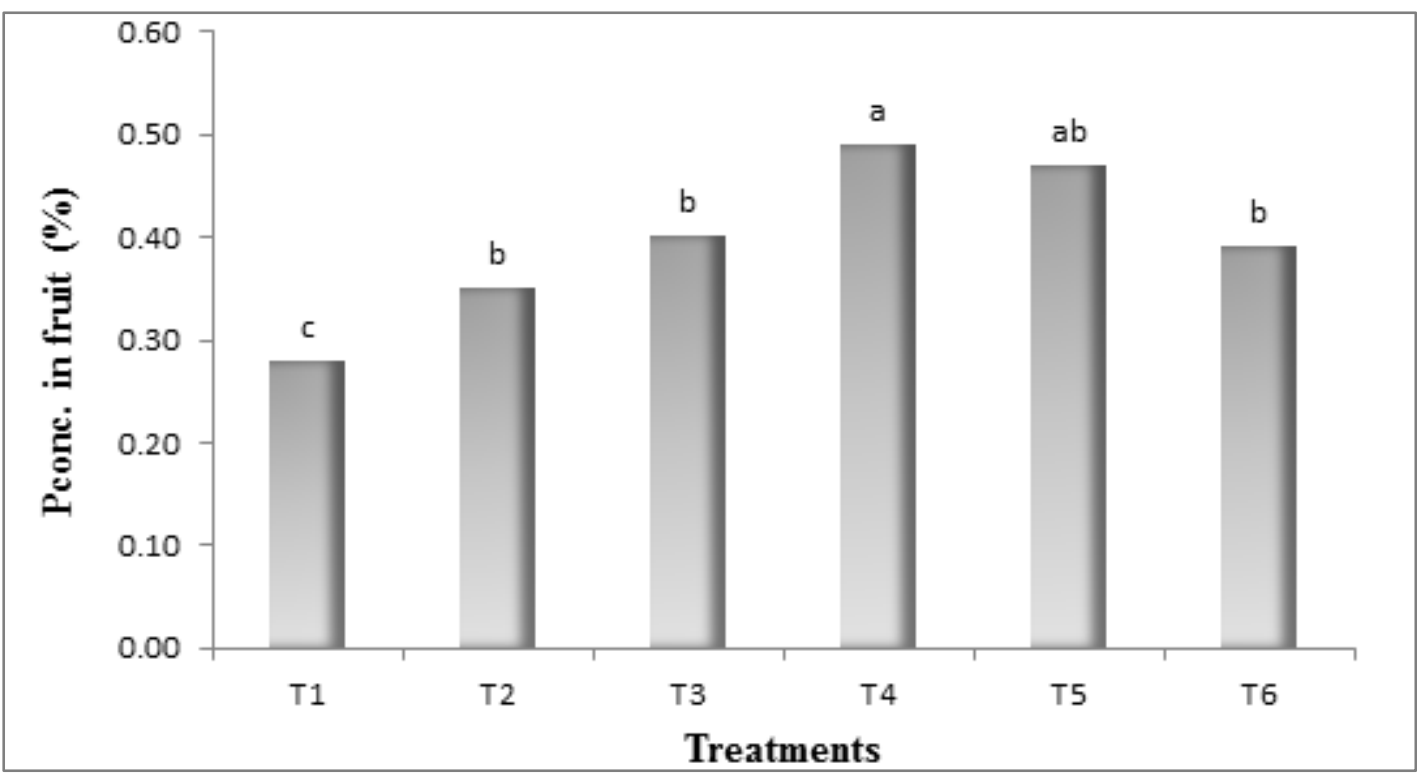

Figure 5. Effect of different PGPRs on P concentration in fruit (\%) 
Table 3. Isolates screened on basis of IAA equivalents $\left(\mu \mathrm{gml}^{-1}\right) \&$ Solubilization Efficiency and Biochemical tests

\begin{tabular}{ccccc}
\hline Isolates & $\begin{array}{c}\text { IAA } \\
\text { equivalents } \\
(\boldsymbol{\mu g} \text { mL-1) }\end{array}$ & $\begin{array}{c}\text { Solubilization } \\
\text { Efficiency } \\
\text { (SE) }\end{array}$ & $\begin{array}{c}\text { Methyl } \\
\text { red } \\
\text { Test }\end{array}$ & $\begin{array}{c}\text { Citrate } \\
\text { Test }\end{array}$ \\
\hline Az 10 & 13.0 & - & + & + \\
As6 & 11.4 & - & + & + \\
BS2 & 16.6 & 235.0 & + & + \\
PS 9 & 18.2 & 243.0 & + & + \\
Rh5 & 10.2 & - & + & + \\
\hline
\end{tabular}

*Values are the mean of three repeats same letters are not statistically different at $\mathrm{P}<0.05$ according to the least significant difference (LSD) test.

\section{REFERENCES}

[1] A. Esitken, H. Karlidag, S. Ercisli, M. Turan and F. Sahin. The effect of spraying a growth promoting bacterium on the yield, growth and nutrient element composition of leaves of apricot (Prunusarmeniaca L. cv. Hacihaliloglu). Australian Journal of Agricultural Research, Vol.54, 377-380, 2003.

[2] A. Gholami, S. Shahsavani and S. Nezarat, The Effect of Plant Growth Promoting Rhizobacteria (PGPR) on Germination, Seedling Growth and Yield of Maize, World Academy of Science, Engineering and Technology, Vol. 49, 19-24, 2009.

[3] A. Salantur, S. Ozturk, F. Akten, Sahin and F. Donmez. Effect of inoculation with non-indigenous and indigenous rhizobacteria of Erzurum (Turkey) origin on growth and yield of spring barley. Plant and Soil, Vol. 275, 147-156, 2006.

[4] A. Salantur., A. Ozturk and S. Akten, Growth and yield response of spring wheat (Triticumaestivum L.) to inoculation with rhizobacteria. Plant Soil and Environment, Vol.52, No.3, 111-118, 2006.

[5] A.C. Gaur. Phosphate solubilizing microorganisms as biofertilizers, Omega Scientific Publisher, New Dehli, 176, 1990.

[6] A.E. Richardson, J.M. Barea, A. M. McNeill, C. Prigent Combaret. Acquisition of phosphorus and nitrogen in the rhizosphere and plant growth promotion by microorganisms. Plant and Soil, Vol. 321, 305-339, 2009.

[7] B. Hameeda, G. Harini, O.P. Rupela, S.P. Wani, G. Reddy. Growth promotion of maize by phosphate-solubilizing bacteria isolated from composts and macrofauna. Microbiology Research, Vol. 163, 234-242, 2008.

[8] B. Russell, B. Hugo and G. A. J. Ayliffo. Principles and practices of disinfection, preservation and sterilization. Black Wall Scientific, London, 1982.

[9] C. Nguyen, W. Yan, F. Le Tacon and F. Lapeyrie (1992). Genetic variability of phosphate solubilizing activity dicaryotic mycelia of the ectomycorrhizal fungus Laccaria bicolor (Maire) P.D. Orton, Plant and Soil, Vol.143, 193199, 1992

[10] D. Egamberdiyeva. The effect of plant growth promoting bacteria on growth and nutrient uptake of maize in two different soils. Applied Soil Ecology, Vol. 36, No. 2-3, 2007.

[11] D.Claus. Anreicherungen and Direktisolierungen aerobe sporenbilder Bakterien. In: Anreicherunskultur and Mutantenauslese (ed. H. G. Schlegel) pp337-362. Gustav Fischer-Verlag, Stuttgart, 337-362, 1964.

[12] D.G.R. Steel, J. H. Torrie and D. A. Dicky. Principles and Procedures of Statistics- A Biometrical Approach.3rd Edition, Mc GrawHill Book International Co., Singapur,204-227, 1997.

[13] E. Elkoca, F. Kantar, F. Sahin and F. Donmez. Nitrojen bakterileriyle aşılamanın şeker pancarinda bitki gelişimi üzerine etkisi. Türkiye 4.Tarla Bitkileri Kongresi, pp. 285-289, 17- 21 Eylul, Tekirdag.2001

[14] E.Yildirim, K. Huseyin, T. Metin, D. Atilla and G. Fahrettin. Growth, Nutrient Uptake, and Yield Promotion of Broccoli by Plant Growth Promoting Rhizobacteria with Manure. Hort. Science Vol. 46, No.6, 932-936, 2011.

[15] F. Sahin, R. Kotan, E. Demirci and S.A. Miller. Effects of Actigard and some antagonists in biological control of bacterial spot disease on tomato and pepper. kinligi. Ataturk Universitesi Ziraat Fakultesi Dergisi, Vol. 31, 11-16, 2000.

[16] H. Asghar, Z. Zahir, M. Arshad and A. Khaliq. Relationship between in vitro production of auxins by rhizobacteria and their growth promoting activities in Bras- sica juncea L.," Biology Fertility of Soils, Vol. 35, No. 4,231-237, 2006.

[17] I.R. Pikovskaya. Mobilization of phosphorus in soil in connection with vital activity of some microbial species. Microbiology, Vol. 17, 362-70, 1948.

[18] J. Han, L. Sun, X. Dong, Z. Cai ,X. Sun, H. Yang, Y. Wang, W. Song. Characterization of a novel plant growth-promoting bacteria strain Delftia tsuruhatensis HR4 both as a diazotroph and a potential biocontrol agent against various plant pathogens. Systematic and Applied Microbiology, Vol. 28, 66-76, 2005.

[19] J.M. Whipps. Microbial interaction and biocontrol in the rhizosphere. Journal of Experimental Botany, Vol. 52,487-512, 2001.

[20] J.W. Kloepper, A. Gutierrez Estrada, J.A. Mclnroy. Photoperiod regulates elicitation of growth promotion but not induced resistance by plant growth-promoting rhizobacteria. Canadian Journal of Microbiology, Vol.53,159-167, 2007.

[21] K. Shaukat, S. Affrasayab and S. Hasnain, Growth responses of Helianthus annus to plant growth promoting rhizobacteria used as a biofertilizer. International Journal of Agricultural Research, Vol. 1, No. 573-581, 2006.

[22] M. Govindappa, V. Ravishankar, Rai and S. Lokesh. Screening of Pseudomonas fluorescens isolates for biological control of macrophomina phaseolina root-rot of safflower. African Journal of Agricultural Research, Vol. 6 , No. 29, 2011

[23] M. Sarwar, D. A. Arshad, W. T. Martens, J. R Frankenberger. Tryptophan dependent, Vol.147, 207-215, 1992.

[24] M.A. Mia. Baset, Z.H. Shamsuddin, Z. Wahab, M. Marziah. Effect of plant growth promoting rhizobacterial (PGPR) 
inoculation on growth and nitrogen incorporation of tissue-cultured musa plantlets under nitrogen-free hydroponics condition. Australian Journal of Crop Science, Vol. 4,85-90, 2010.

[25] M.A. Whitelaw. Growth promotion of plants inoculated with phosphate-solubilizing fungi. Advances in Agronomy, Vol.69,99-151, 2000.

[26] M.E. McCully. Niches for bacterial endophytes in crop plants: a plant biologist's view. Australian Journal of Plant Physiology, Vol. 28, 983-990, 2001.

[27] M.J. Vincent. A manual for the practical study of root-nodule bacteria. IBP Handbook Number 15, Blackwell, Oxford, 1970.

[28] P. Hinsinger. Bioavailability of soil inorganic $\mathrm{P}$ in the rhizosphere as affected by root induced chemical changes: a review. Plant and Soil, Vol. 237,173-195, 2001.

[29] P.N. Bhattacharya, D.K. Jha. Plant growth-promoting rhizobacteria (PGPR): emergence in agriculture. World Journal of Microbiology and Biotechnolology, Vol.28, $1327-1350,2012$.

[30] P.V. Minorsky. On the inside. Plant Physiology, Vol.146, $323-324,2008$

[31] R. Cakmakci, F. Donmez, A. Aydın and F. Sahin. Growth promoting of plants by plant growth-promoting rhizobacteria under greenhouse and two different field soil conditions. Soil Biology \& Biochemistry, Vol.38, 1482-1487, 2006.

[32] R. Maliha, S. Khalil, N. Ayub, S. Alam and F. Latif. Organic acids production and phosphate solubilization by phosphate solubilizing microorganisms (PSM) under in vitro conditions. Pakistan Journal of Biological Science, Vol. 7, 187-196. 2004.
[33] R.N. Krieg and J. G. Holt. Bergey's Manual of Systematic Bacteriology, Williams and Wilkins, Baltimore, MD,USA, Vol. 1, 694, 1984.

[34] S. C. Nautiyal. An efficient microbiological growth medium for screening phosphate solubilizing microorganism. FEMS. Microbiology. Let. Vol.170, 265-270, 1999.

[35] S. Dobbelaere, A. Croonenborghs, A. Thys, D. Ptacek et al Responses of agronomically important crops to inoculation with Azospirillum. Australian Journal of Plant Physiology, Vol.28, 871-879, 2001.

[36] S. Mantelin, B. Touraine. Plant growth-promoting bacteria and nitrate availability: impact of development and nitrate uptake. Journal of Experimental Botany, Vol.55,27-34, 2004

[37] V. Gravel, C. Martinez, H. Antoun, R.J. Tweddell. Control of greenhouse tomato root rot (Pythium ultimum) in hydroponic systems using plant growth-promoting microorganisms. Canadian Journal of Plant Pathology, in press, 2006.

[38] V. Gravel, H. Antoun and R.J. Tweddell. Growth stimulation and fruit yield improvement of greenhouse tomato plants by inoculation with Pseudomonas putida or Trichoderma atroviride: Possible role of indole acetic acid (IAA). Soil Biology and Biochemistry, Vol.39, 1968-1977, 2007.

[39] Vessey, J.K., 2003. Plant growth promoting rhizobacteria as biofertilizers, Plant Soil., 255: 571-586.

[40] Y.Bashan, L.E.Bashan. How the plant growth-promoting bacterium Azospirillum promotes plant growth a critical assessment. Advances of Agronomy, Vol. 108, 77-136, 2010 . 